\title{
Improved student outcomes through use of direct instruction in the laboratory
}

Heneghan, Mary

Institute of Technology Sligo, Ireland (Heneghan.mary@itsligo.ie)

Cronin, Michael

University College Cork, Ireland (m.cronin@ucc.ie)

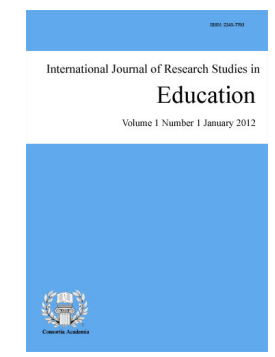

McCabe, Anthony $\bowtie$

Institute of Technology Sligo, Ireland (mccabe.tony@itsligo.ie)

ISSN: 2243-7703 Online ISSN: 2243-7711

OPEN ACCESS

\section{Abstract}

Student centered learning approaches are almost universally applied in modern education settings. Student centered models often use inquiry-based learning and student teamwork in their delivery. However, not all students benefit equally from these inquiry-based approaches and some may benefit from a more instructor-led approach. This study investigates the impact of either direct instruction or teamwork on student outcomes in a biology laboratory class. Students were taught either by demonstration and teamwork in pairs, or with individual or small group direct instruction, during two laboratory experiments of varying difficulty. Following the laboratory classes, the students were assessed individually. Three outcomes were assessed: laboratory skills, understanding and efficiency. Our findings show that direct instruction had significant benefits to students' ability to execute complex laboratory tasks and that these tasks were executed significantly quicker when compared to students taught by demonstration and working in teams. These significant differences were not apparent when students performed the easier and less complex experimental procedure. The data suggests that when designing curriculum, consideration should be given to how complex procedures are taught, and where possible, students should avail of direct instruction to improve student outcomes.

Keywords: instructor-led; individual teaching; improved skills; grade improvement 


\section{Improved student outcomes through use of direct instruction in the laboratory}

\section{Introduction}

In recent years, a debate has emerged regarding the benefits of student centered versus teacher centered learning approaches in education. In teacher-centered instruction, teaching is led by the educator. In this scenario, students observe, listen and follow the instruction of the educator; learning is a passive activity. In comparison to this is the constructivist vision of education. This approach is student centered; students are more actively involved in the learning process. In the constructivism approach, problems and subject matter are shared between the educator and student and between students. Students use questioning, research, discussion and practice to address the problem at hand (O’Neill \& McMahon, 2005).

Student teamwork often accompanies student-centered learning exercises. Constructivism and teamwork complement each other as they both utilize active and self-directed learning. The benefits of teamwork have long been acknowledged and adopted by educational institutes in their teaching methodologies. Teamwork benefits students in many ways, and its positive effects and outcomes have long been articulated in the literature. Teamwork can aid development of critical thinking (Gokhale, 1995; Fung, To, \& Leung, 2016), social and communication skills (Mendo-Lázaro, León-del-Barco, Felipe-Castaño, Polo-del-Río, \& Iglesias-Gallego, 2018; Hassanien, 2006) and active learning (Faust \& Paulson, 1998) and numerous studies indicate improved learning and academic scores (Springer, Stanne, \& Donovan, 1999; Rudina, 2011).

Advocates of constructivism suggest that it is through inquiry-based unassisted discovery, active learning and the students' ultimate experiences (of these processes) that learning is acquired (Bada, 2015; O'Neill \& McMahon, 2005). However, constructivism protagonists argue that there is little hard evidence that inquiry-based learning works, or at least that it benefits all equally (Kirschner, Sweller, \& Clark, 2006). Meta-analysis of studies investigating inquiry-based learning has questioned its benefits compared to direct teaching methods (Alfieri, Brooks, \& Aldrich, 2011). Problems also exist with student teams, often used in inquiry-based learning, with evidence suggesting that not all students benefit equally from these approaches. Studies have highlighted negative experiences associated with group work such as grade allocation, loss of group cohesion and interdependence and affective tone (Teng \& Luo, 2015; Chang \& Brickman, 2018). What is clear from the literature is that if teamwork exercises are not professionally managed, from the educator's point of view, with clear design and objectives for the group members, success is far less likely (Hansen, 2006).

There is an alternative body of research which suggests that in comparison, increasing the focus on the individual learner in terms of direct instruction and instructional time, in a teacher led fashion, can enhance academic outcomes of that student. The direct-instruction theory is teacher led, but in an ideal scenario it contains the following key attributes; the teacher should aim to reduce the difficulty of the task in initial practice, the teacher should use scaffolds and guidance to support students and finally, the teacher should provide immediate and supportive feedback in order for students to benefit (Rosenshine, 2008). Instructional time alone has been shown to impact student outcomes with several studies suggesting that increasing instruction time improves student grades (Cattaneo, Oggenfuss, \& Wolter, 2017; Brown \& Saks, 1986). This approach is in stark contrast to the student-centered, inquiry led approach which is widely adopted in educational institutes globally and encompasses active learning, group learning and problem-based learning teaching approaches. All this suggests that a more nuanced and balanced approach to teaching and learning, incorporating direct instruction approaches in certain situations may play a significant role in improving the outcomes from our increasingly diverse classrooms and lecture halls.

In this current study we compare the impact of direct instruction and teamwork in the execution and understanding of two experimental protocols in a laboratory module within an undergraduate education setting. 


\section{Methods}

\subsection{Class background}

The participants in the study consisted of 47 students from the Institute's Medical Biotechnology and Biomedical Sciences programs. Both these programs study the introductory laboratory module Animal Cell Culture. The module is taught at level 7 (QQI, 2019). This module is taught to all students by the same two instructors.

\subsection{Study design}

Prior to the beginning of the laboratory element, students were randomly assigned into two groups, A and B. The laboratory classes were run during different times in the teaching week for each of these groupings. Two skills which these students must master are (1) preparing and working aseptically in a biological safety cabinet (BSC) and (2) counting animal cells using a haemocytometer slide (cell counting). Both exercises are necessary for the module learning outcomes and future work in cognate areas however they differ considerably in technical difficulty. Preparing and working aseptically in a biological safety cabinet would be considered a simpler, more straightforward task when compared to preparing samples and microscopes and determining cell concentration using haemocytometers.

\subsection{Teaching methods}

Group A and B were both taught these techniques in one of two ways. Group A were taught Biological safety cabinet aseptic work on an individual basis with direct instruction and mentoring from the instructor and then proceeded to practice the technique on their own under the watchful eye of the lecturer. For group B, this technique was taught as a whole class demonstration, and subsequently the students worked in teams of two and practiced the technique while following their laboratory manual in an unassisted manner. For group B, there was minimal interaction with the lecturers other than if issues arose and when called upon by the students (student-centered).

For the second laboratory task, cell counting, the approach for each group switched. Group A were taught how to prepare cells, slides and microscopes for counting through class demonstration and subsequently worked in teams of two as the lecturers observed and helped only when requested (student-centered). Conversely, group B were taught this skill using direct instruction in small groups of 3-5 students. In these sessions, the technique was explained and demonstrated to the small group and the students subsequently worked in the laboratory independently while the lecturers moved from student to student mentoring each one individually in the technique and providing immediate feedback and advice.

\subsection{Student assessment}

Students were individually assessed one week following training on biological safety cabinet work and two weeks following their training on cell counting. A three-pronged approach was adopted for the assessment. Firstly, students were assessed on their practical skill in executing the tasks. This was examined by the instructors observing the students' technique and scoring it accordingly. Secondly, the students' understanding of the technique was assessed by way of a closed book quiz and thirdly, the time it took students to complete each task was recorded to reflect their efficiency.

\subsection{Statistical analysis}

The three outcome variables (Understanding, Practical Skill and Completion Time) were compared between teaching methods (Direct instruction/Teamwork) using analysis of variance (ANOVA) models for a repeated 
Heneghan, M., Cronin, M., \& McCabe, A.

measures design. Teaching method, test (Biological Cabinet Work/Cell Counting) and the interaction between these were included as factors. Comparisons between teaching methods were made using linear contrasts based on the interaction term. The student's GPA was included as a covariate. Unstructured variance-covariance matrices were applied. A logarithmic transformation was required for completion time to normalize the residuals. Diagnostic checks confirmed the ANOVA models were adequate. The level of significance used was $5 \%$ and all statistical analyses were performed in SAS® (Version 9.4).

\section{Results}

\subsection{Overall student scores}

When assessing both experiments, the scores for understanding and practical skills were significantly higher for the biological safety cabinet experiment compared to the cell counting experiment and the time taken to complete the biological safety cabinet work was significantly shorter (see Tables 1, 2 and 3). For example, in Table 1, the average score for total students executing the BSC experiment was $76 \%$ against $58 \%$ for the cell counting experiment. These differences are present regardless of whether the student worked individually or in the group. This outcome likely reflects the difference in overall complexity between both the experiments; the biological safety cabinet work being considered easier and less difficult to comprehend and execute.

\subsection{Student understanding}

The students' understanding of the concepts which pertained to the laboratory class was assessed by a short quiz. Each student, regardless of whether they executed the laboratory in a team or with direct instruction, took the exam individually. The results from this quiz are shown in Table 1. The results from this assessment of understanding show that the average score for students taught through direct instruction was $70 \%$ whereas the average score for those working in teams was $64 \%$. In this assessment, the increased scores for direct instruction compared to teamwork is present regardless of the technique being assessed (biological safety cabinet assessment or cell counting assessment). Despite the trend toward increased understanding, the differences between direct instruction or teamwork are not significant, see statistical analysis in Table 1.

\section{Table 1}

The impact of instruction type on student understanding

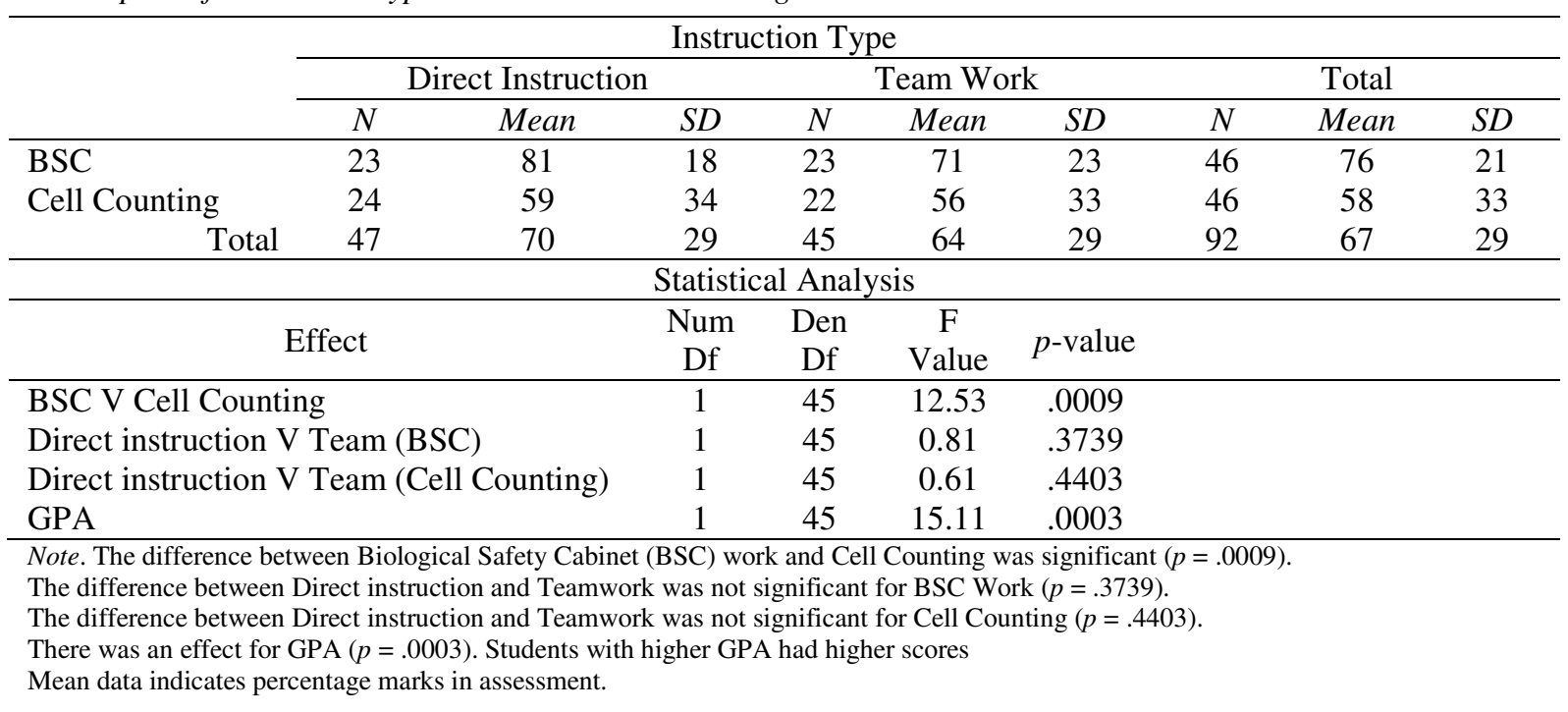

\subsection{Student practical skills assessment}

In the week following the laboratory class, the students' practical skills were assessed. The students were

16 Consortia Academia Publishing (A partner of Network of Professional Researchers and Educators) 
asked to execute the procedure which they were taught in the previous laboratory class (either biological safety cabinet preparation or cell counting with a haemocytometer). The students were observed while executing the procedure and key steps in the procedures were identified and scored while mistakes were also noted. For example, for the biological safety cabinet work, students were observed and assessed for the pre-preparation of the biological cabinets and for their handling of bottles and reagents while working within the safety cabinet. For the cell counting assessment, an example of what was assessed was the students' preparation of cell samples and loading onto the haemocytometer. The results from the practical assessment are recorded in Table 2.

The overall mean score for all direct instruction students across both experiments was $79 \%$ whereas the mean score for all students working in teams was $72 \%$. Statistical analysis of these scores indicates that this difference was insignificant. However, when analyzed separately, there is a significant increase in the practical skills scores for the cell counting experiment from the direct instruction students versus those working in teams (76\% individual mean versus $66 \%$ group mean, $p=.0076$ ) compared to the biological safety cabinet experiment ( $82 \%$ direct instruction mean versus $78 \%$ teamwork mean).

\section{Table 2}

The impact of instruction type on student skills

\begin{tabular}{|c|c|c|c|c|c|c|c|c|c|}
\hline \multicolumn{10}{|c|}{ Instruction Type } \\
\hline & \multicolumn{3}{|c|}{ Direct Instruction } & \multicolumn{3}{|c|}{ Team Work } & \multicolumn{3}{|c|}{ Total } \\
\hline & $N$ & Mean & $S D$ & $N$ & Mean & $S D$ & $N$ & Mean & $S D$ \\
\hline BSC & 23 & 82 & 16 & 23 & 78 & 15 & 46 & 80 & 16 \\
\hline Cell Counting & 24 & 76 & 14 & 22 & 66 & 20 & 46 & 71 & 18 \\
\hline Total & 47 & 79 & 15 & 45 & 72 & 19 & 92 & 76 & 17 \\
\hline \multicolumn{10}{|c|}{ Statistical Analysis } \\
\hline \multicolumn{3}{|c|}{ Effect } & $\begin{array}{c}\text { Num } \\
\text { Df }\end{array}$ & $\begin{array}{c}\text { Den } \\
\text { Df }\end{array}$ & $\begin{array}{c}\mathrm{F} \\
\text { Value }\end{array}$ & $p$-value & & & \\
\hline \multicolumn{3}{|c|}{ BSC V Cell Counting } & 1 & 45 & 9.24 & .0039 & & & \\
\hline \multicolumn{3}{|c|}{ Direct instruction V Team (BSC) } & 1 & 45 & 0.01 & .9275 & & & \\
\hline \multicolumn{3}{|c|}{ Direct instruction V Team (Cell Counting) } & 1 & 45 & 7.80 & .0076 & & & \\
\hline \multicolumn{3}{|l|}{ GPA } & 1 & 45 & 13.09 & .0007 & & & \\
\hline \multicolumn{10}{|c|}{$\begin{array}{l}\text { Note. The difference between Biological Safety Cabinet (BSC) work and Cell Counting was significant } \\
\text { The difference between Direct instruction and Teamwork was not significant for BSC work }(p=.9275) \text {. } \\
\text { The difference between Direct instruction and Teamwork was significant for Cell Counting }(p=.0076) \text {. } \\
\text { There was an effect for GPA }(p=.0007) \text {. Students with higher GPA had higher scores. } \\
\text { Mean data indicates percentage marks in assessment. }\end{array}$} \\
\hline
\end{tabular}

\subsection{Completion time}

The time taken to complete each procedure was recorded during the assessment of each experimental procedure. This was used to assess the effect of treatment (direct instruction versus teamwork) on the students' efficiency. Collectively, there was no significant difference in the time taken to complete the procedures between direct instruction students versus those working in a team (794s versus $947 \mathrm{~s})$. However, in a similar finding to the assessment of practical skills, the time taken to complete the more complex cell counting procedure was significantly shorter for the directly instructed students against those students working in a team (1137s vs $1484 \mathrm{~s}$, $p=.0021$ ), whereas there was no significant difference in the time taken to complete the simpler biological safety cabinet assessment task (436s versus 434s), see Table 3.

\subsection{Effect of student GPA}

In order to ascertain if the students' overall ability influenced the results of the assessments, the student end of year GPA (grade point average) was considered in the analysis. Analysis shows that GPA did affect the assessment of the students understanding and practical skills. The significant benefits observed in understanding and practical assessments were observed in all the students assessed, regardless of GPA, and these increases were in line with students' GPA, as the student GPA increases so did their scores. There was no effect of GPA on time 
Heneghan, M., Cronin, M., \& McCabe, A.

taken to complete each experiment. See Tables 1, 2, and 3.

Table 3

The impact of instruction type on completion time

\begin{tabular}{|c|c|c|c|c|c|c|c|c|c|}
\hline \multicolumn{10}{|c|}{ Instruction Type } \\
\hline & \multicolumn{3}{|c|}{ Direct Instruction } & \multicolumn{3}{|c|}{ Team Work } & \multicolumn{3}{|c|}{ Total } \\
\hline & $N$ & Mean & $S D$ & $N$ & Mean & $S D$ & $N$ & Mean & $S D$ \\
\hline BSC & 23 & 436 & 145 & 23 & 433 & 107 & 46 & 434 & 126 \\
\hline Cell Counting & 24 & 1137 & 257 & 22 & 1484 & 483 & 46 & 1303 & 416 \\
\hline Total & 47 & 794 & 410 & 45 & 947 & 632 & 92 & 869 & 533 \\
\hline \multicolumn{10}{|c|}{ Statistical Analysis } \\
\hline \multicolumn{3}{|c|}{ Effect } & $\begin{array}{l}\text { Num } \\
\text { Df }\end{array}$ & $\begin{array}{l}\text { Den } \\
\text { Df }\end{array}$ & $\begin{array}{c}F \\
\text { Value }\end{array}$ & \multicolumn{4}{|l|}{$p$-value } \\
\hline \multicolumn{3}{|c|}{ BSC V Cell Counting } & 1 & 45 & 447.51 & .0001 & & & \\
\hline \multicolumn{3}{|c|}{ Direct instruction V Team (BSC) } & 1 & 45 & 0.01 & .9136 & & & \\
\hline \multicolumn{3}{|c|}{ Direct instruction V Team (Cell Counting) } & 1 & 45 & 10.69 & .0021 & & & \\
\hline \multicolumn{3}{|c|}{ GPA } & 1 & 45 & 1.21 & .2763 & & & \\
\hline \multicolumn{10}{|c|}{$\begin{array}{l}\text { Note. The difference between Biological Safety Cabinet (BSC) work and Cell Counting was significant }(p< \\
\text { The difference between Direct instruction and Teamwork was not significant for BSC Work }(p=.9136) \text {. } \\
\text { The difference between Direction instruction and Teamwork was significant for Cell Counting }(p=.0021) \text {. } \\
\text { There was no effect for GPA }(p=.2763) \text {. }\end{array}$} \\
\hline
\end{tabular}

\section{Discussion}

In planning and designing educational modules and programs there has been a seismic shift in recent years away from the rote learning and teacher centered lecture and listening practices of previous generations. New models for learning embrace constructivist-type student centered approaches. Adoption of unassisted discovery, inquiry and problem-based learning are now commonplace in undergraduate teaching. In these new approaches, the students are presented with the problem and the means to find the answer and learn by investigation, peer learning, discussion, debate and experimentation. Evidence in support of student-centered learning is well documented. Studies have shown student centered learning approaches contribute to increased understanding, study skills and grades (Springer et al., 1999; Rudina, 2011). In many instances, these student-centered learning approaches encompass group or teamwork. This teamwork aspect also contributes to more abstract aspects of learning such as motivation, participation, and leadership skills.

Of late however, there have been arguments made for a more balanced approach to teaching and learning. In the concept of universal design for learning, there is no one shoe fits all model of teaching, and a balanced approach must be adopted, inclusive of all student learning styles and abilities and for whom student centered learning may not be a good fit. To this end, an approach which embraces direct instruction and less inquiry-based learning may be more beneficial to certain students executing certain learning exercises.

Accordingly, our study investigates the impact of a direct instruction teaching approach provided to individual students against an unassisted, or minimally assisted student-centered approach in which the students work together in pairs to complete laboratory tasks. The study investigated the students' understanding, execution and efficiency during a biology-based laboratory class in a level 7 module (QQI). Once the students were taught the procedures, by which ever mode of teaching, they were assessed individually.

The two exercises executed by the students differed in complexity. The first, a biological safety cabinet (BSC) procedure, is considered a simpler task than the second procedure, cell counting, which utilizes a haemocytometer and encompasses multiple steps and intricacies in comparison. This difference is evident from the data. Regardless of the teaching method, all students performed significantly better in the simpler BSC procedure when compared to the intricate cell counting exercise when assessed for understanding and laboratory skills. Students also executed the BSC procedure significantly quicker than the cell counting procedure.

18 Consortia Academia Publishing (A partner of Network of Professional Researchers and Educators) 
Improved student outcomes through use of direct instruction in the laboratory

The students understanding of the exercise was assessed by way of a paper-based quiz within two weeks following the laboratory class. Analysis of the data reveals a trend toward improved understanding in the students who were given direct instruction compared to those working in their teams, but this difference is insignificant. The minimally assisted students, working in teams, had no better understanding of the problem when compared to those students who executed the experiment under direct instruction. This would seem to be in line with other studies which have demonstrated little or no advantage to student centered approaches in this regard (Mayer, 2004).

The next outcome which was assessed was the students' practical laboratory skills. Each procedure was taught using a different method, either by direct instruction or by class demonstration followed by teamwork. Once again, students were assessed individually for their ability to execute the laboratory skills involved. In this analysis, differences in the outcome arose between the two procedures. In the simpler BSC procedure, there was no significant difference between either teaching method. However, when data from the more difficult cell counting procedure was assessed, the students who had direct instruction had significantly higher scores compared to those students working in a team $(p=.0076)$. This suggests a significant advantage for students given direct instruction for intricate, multi-step procedures.

The final outcome assessed in our study was student efficiency, as measured by the time taken to execute the laboratory procedures during the skills assessment element. Our data shows that the students who were taught using direct instruction were significantly quicker at executing and successfully completing the complex cell counting task compared to the students who had worked on the exercises in teams. This difference was not present when students executed the simpler biological safety cabinet experiment. This difference may result from the sharing of tasks, which is normally evident in teamwork. When teams delegate work, individuals within that team may not necessarily experience and execute the complete process, which in turn may account for their slower execution of the procedure during the assessment.

Together, our data supports previous studies which indicate little benefit for the students from strict student-centered approaches. Mayer (2004) contends that without significant guidance and assessment structure, there is little evidence that unassisted discovery benefits student learning and that it does not improve problem-solving. Moreover, when it comes to relatively intricate techniques, our study suggests a significant advantage to students who are given direct instruction. This would support other studies which have shown that increased instruction time and direct instruction is beneficial for student outcomes. Many have argued that discovery-based learning approaches alone are unlikely to develop student learning and that some degree of guidance and direct instruction is likely to be required (Klahr, 2009; Clark, 2009). The suggestion is, that under some circumstances, direct instruction or guidance may be required for a student to fully grasp a concept first and this then becomes the basis for discovery learning (Klahr, 2009). Klahr argues that a certain amount of direct instruction time reduces variations in instructional times, feedback, instructional sequences and generalization of skills which may accompany solely discovery-based learning activities. Klahr and others also suggest that unassisted learning tasks can overwhelm a student's cognitive space leading to reduced performance and learning outcomes when compared to students who are provided with some directed instruction (Klahr \& Nigram, 2004; Walkingham \& Bernacki, 2018). This may explain, at least in part, the lower scores observed in our minimally assisted students when executing the more complex cell counting procedure. In our study, no difference exists when executing simple tasks, but a significant advantage (increased grade) is gained by students under direct instruction when undertaking a more intricate procedure.

Clark (2009) proposes that the key aspects of instructional guidance are 1) accurate and complete demonstration of how and when to perform an application and 2) the provision of immediate and corrective feedback on performance. When these are provided, student outcomes are improved. In our direct instruction approach, the instructor worked with the student on a one to one level during both experiments and tutored and interacted with the student as they practiced the experiments. The instructor intervened immediately when the student was incorrectly executing steps and this is likely to have contributed to the improved outcomes in 
practical skills and time efficiency for these students, particularly when executing the more intricate procedure.

In previous studies, increased instruction time has been shown to have particular benefits for students who are academically weaker (Brown \& Saks, 1986) and there have been suggestions that weaker students might benefit from additional instruction time (Cattaneo et al., 2016). This might also have been an expectation in our study. However, our data does not indicate a particular academic (grade) benefit for weaker students. Alternatively, our data corroborates other studies which indicate that instruction time given to students benefits all students and is of no particular benefit to academically weaker students. Our data shows that the overall GPA (grade point average) of the student had an effect when assessing understanding and practical skills: as GPA increased so did the assessment scores. This suggests that direct instruction did not particularly benefit the weaker students, rather all students benefitted from the direct instruction. There was no effect of GPA in the time taken to execute the procedure; students with higher GPA did not execute the procedures any quicker than students with lower GPAs.

Practically speaking, incorporating direct instruction requires some planning. The tasks identified for direct instruction require teaching in very small groups or to individuals and this will likely require scheduling. In the typical university laboratory class, students arrive en masse for the lesson which is executed in a specified time, perhaps two or three hours. In our study, when using direct instruction, each student attended the laboratory for short bursts of time, from 15-30 minutes. For the instructors, this ultimately means repeating the task at hand in order to teach each student or small student groups individually. If we take the cell counting laboratory class used in this study as an example, this laboratory class is normally allocated a 3-hour laboratory slot for the student group. However, when teaching using direct instruction, the students attended the laboratory for shorter 30-minute timeslots leaving the remaining timetabled laboratory time to practice on the mathematical calculations and hypothetical data related to the technique executed. So, incorporating direct instruction into the laboratory may require some timetable changes and more rigorous scheduling, and also relies on student cooperation and adherence to new schedules to ensure smooth running of the class.

Quantitative analysis comparing direct instruction to constructivist alternatives in biological laboratory settings is scarce, particularly studies which are controlled and statistically analyzed (Beck, Butler, \& Burke da Silva, 2014). Our study quantitatively compares direct instruction to student led activity by analyzing three outcomes: understanding, practical skills and efficiency, all in the same student group, experiencing both teaching approaches. Our data demonstrates significant improvement in students' skill level and efficiency from direct instruction and working alone. Additionally, our study shows that this effect is only evident when students undertake difficult rather than simpler laboratory tasks, thus identifying a determining factor for deciding when direct instruction is most useful within a laboratory setting.

\section{Conclusion}

There are a number of implications arising from this research and they impact on a number of stakeholders in undergraduate education. From the viewpoint of the instructor and curriculum designers, the data points to a required rethink in how certain activities are taught in undergraduate laboratory courses. There has been a major shift to expanding inquiry and discovery led approaches to education, including laboratory science education (Ibrahim, Johari, Hui, \& Safiah, 2013; Beck et al., 2014). This approach has benefits as previously outlined, but there is a viewpoint that it may not have the desired impact on all students (Kirschner, Sweller, \& Clark, 2006). Designing an inquiry-based laboratory element were students are asked to design and problem-solve in a discovery fashion, without being capable in the execution of the basic and fundamental practical steps, is ill-advised and unlikely to produce desired outcomes. It is likely that a balanced approach encompassing elements of both teaching methods is required to achieve the shared goal of improved student learning (Chase \& Klahr, 2017).

From the instructor's perspective, the adoption of direct instruction requires an added focus on scheduling, 
Improved student outcomes through use of direct instruction in the laboratory

so each student experiences the direct instruction during the laboratory time. However, this does not necessarily mean that the overall time allocation for the lesson increases. Our study did not require additional laboratory time allocation and so improved outcomes were achieved for the same resource, and this is vitally important for our students and institutions in this competitive global education market. Additional benefits for the instructor exist from working closely with students; firstly, individual student weaknesses which can be addressed specifically and secondly, problems which arise across all students can be identified much quicker, which can then be addressed by improving student instruction and design.

For the student, these short bursts of direct instruction allow for additional time to study the outcomes of the experiments and plan and design for subsequent laboratory classes related to, or which follow on from the tasks. Our study shows that for critical and intricate techniques, the students benefit from direct instruction, which in our case, leads to improved ability and efficiency when executing technically intricate procedural tasks. These technical tasks are fundamentals and arguably a prerequisite for inquiry and discovery led teaching in the laboratory. Mastering such key skills also enables students to be 'work ready'. Employers are another key stakeholder who benefits from this approach. Lack of proficiency in key relevant technical skills in new graduates is an issue often highlighted by industry and potential employers (Thompson et al., 2018; Husain, 2012). One of the key missions of universities is to produce technically proficient graduates and a university who can do so is one which will flourish. Producing science graduates who are more capable in key discipline-specific techniques is surely instrumental to the success of the university, the student and industry and employers and direct instruction can play a key role in achieving this.

\section{References}

Alfieri, L., Brooks, P. J., \& Aldrich, N. J. (2011). Does discovery-based instruction enhance learning? Journal of Educational Psychology, 103(1), 1-18. https://doi.org/10.1037/a0021017

Andersen, S. C., Humlum, M. K., \& Nandrup, A. B. (2016). Increasing instruction time in school does increase learning. Proceeding of the National Academy of Sciences, 113(27), 7481-7484. https://doi.org/10.1073/pnas.1516686113

Bada, S. (2015). Constructivism learning theory: A paradigm for teaching and learning. Journal of Research \& Method in Education, 5(6), 66-70.

Beck, C., Butler, A., \& Burke da Silva, K. (2014). Promoting inquiry-based teaching in laboratory courses: Are we meeting the grade? CBE-Life Sciences Education, 13, 444-452. https://doi.org/10.1187/cbe.13-12-0245

Brown, B. W., \& Saks, D. H. (1986). Measuring the effects of instructional time on student learning: Evidence from the beginning teacher evaluation study. American Journal of Education, 94(4), 480-500. https://doi.org/10.1086/443863

Cattaneo, M. A., Oggenfuss, C., \& Wolter, S. C. (2017). The more, the better? The impact of instructional time on student performance. Education Economics, 25(5), 433-445. https://doi.org/10.1080/09645292.2017.1315055

Chang, Y., \& Brickman, P. (2018). When group work doesn't work: Insights from students. CBE Life Science Education, 17(3), 1-17. https://doi.org/10.1187/cbe.17-09-0199

Chase, C., \& Klahr, D. (2017). Invention versus direct instruction: For some content, it's a tie. Journal of Science Education and Technology, 26, 582-596. https://doi.org/10.1007/s10956-017-9700-6

Clark, R. E. (2009). How much and what type of guidance is optimal for learning from instruction? In S. Tobias \& T. M. Duffy (Eds.), Constructivist theory applied to instruction: Success or failure? (pp. 158-183). New York, NY: Taylor \& Francis.

Faust, J. L., \& Paulson, D. R. (1998). Active learning in the college classroom. Journal on Excellence in College Teaching, 9 (2), 3-24.

Fung, D., To, H., \& Leung, K. (2016). The influence of collaborative group work on students' development of critical thinking: The teacher's role in facilitating group discussions. Pedagogies: An International 
Heneghan, M., Cronin, M., \& McCabe, A.

Journal, 11(2), 146-166. https://doi.org/10.1080/1554480X.2016.1159965

Gokhale, A. (1995). Collaborative learning enhances critical thinking. Journal of Technology Education, 7(1), 22-30. https://doi.org/10.21061/jte.v7i1.a.2

Hansen, R. S. (2006). Benefits and problems with student teams: Suggestions for improving team projects. Journal of Education for Business, 82(1), 11-19. https://doi.org/10.3200/JOEB.82.1.11-19

Hassanien, A. (2006). Student experience of group work and group assessment in higher education. Journal of Teaching in Travel \& Tourism, 6(1), 17-39. https://doi.org/10.1300/J172v06n01_02

Husain, L. (2012). The skills gaps between graduation and employment for bioscience graduates. Retrieved from https://www.ncub.co.uk/blog/skills-gap-bioscience.html

Ibrahim, H. H., Johari, S. K., Hui, P., \& Safiah, Y. (2013). Typical teaching method applied in chemistry experiment. Procedia - Social and Behavioral Sciences, 116(2014), 4946-4954. https://doi.org/10.1016/j.sbspro.2014.01.1054

Kirschner, P. A., Sweller, J., \& Clark, R. (2006). Why minimal guidance during instruction does not work: An analysis of the failure of constructivist, discovery, problem-based, experiential, and inquiry-based teaching. Educational Psychologist, 41(2), 75-86. https://doi.org/10.1207/s15326985ep4102_1

Klahr, D. (2009). To everything there is a season, and a time to every purpose under the heavens: What about direct instruction? In S. Tobias \& T. M. Duffy (Eds.), Constructivist instruction: Success or failure? (pp. 291-310). New York, NY: Routledge/Taylor \& Francis Group.

Klahr, D., \& Nigam, M. (2004). The equivalence of learning paths in early science instruction: Effects of direct instruction and discovery learning. Psychological Science, 15(10), 661-667.

https://doi.org/10.1111/j.0956-7976.2004.00737.x

Mayer, R. E. (2004). Should there be a three-strikes rule against pure discovery learning? The case for guided methods of instruction. American Psychologist, 59(1), 14-19. https://doi.org/10.1037/0003-066X.59.1.14

Mendo-Lázaro S, León-del-Barco B, Felipe-Castaño E, Polo-del-Río M-I \& Iglesias-Gallego D (2018). Cooperative team learning and the development of social skills in higher education: The Variables involved. Frontiers Psychology, 9. https://doi.org/10.3389/fpsyg.2018.01536

O'Neill, G., \& McMahon, T. (2005). Student-centered learning: What does it mean for students and lecturers? In G. O'Neill, S. Moore, \& B. McMullin (Eds.), Emerging issues in the practice of university learning and teaching (pp. 27-36). Dublin: AISHE.

QQI. (2019). National framework of qualification. Retrieved from https://www.qqi.ie/Articles/Pages/National-Framework-of-Qualifications-(NFQ).aspx

Rosenshine, B. (2008). Five meaning of direct Instruction. Center of innovation and improvement. Retrieved from http://www.centerii.org/search/Resources/FiveDirectInstruct.pdf

Rudina, V. (2011). Effects of group learning on the academic performance of University students. Problems of Education in the 21st Century, 33, 111-117.

Springer, L., Stanne, M. E., \& Donovan, S. S. (1999). Effects of Small-Group Learning on Undergraduates in Science, Mathematics, Engineering, and Technology: A Meta-Analysis. Review of Educational Research, 69(1), 21-51. https://doi.org/10.3102/00346543069001021

Stockard, J., Wood, T. W., Coughlin, C., \& Khoury, C. R. (2018). The effectiveness of direct instruction curricula: A meta-analysis of a half century of research. Review of Educational Research Month, 88(4), 479-507. https://doi.org/10.3102/0034654317751919

Teng, C.-C., \& Luo, Y.-P. (2015). Effects of perceived social loafing, social interdependence, and group affective tone on students' group learning performance. Asia-Pacific Education Researcher, 24(1), 259-269. https://doi.org/10.1007/s40299-014-0177-2

Thompson, C., Sanchez, J., Smith, M., Costello, J., Madabushi, A., Schuh-Nuhfer, N., Miranda, R., Gaines, B., Kennedy, K., Tangrea, M., \& Rivers, D. (2018). Improving undergraduate life science education for the biosciences workforce: Overcoming the disconnect between educators and industry. CBE—Life Sciences Education, 17(12), 1-8. https://doi.org/10.1187/cbe.18-03-0047

Walkington, C., \& Bernacki, M.L. (2018). Personalization of instruction: Design dimensions and implications 
Improved student outcomes through use of direct instruction in the laboratory

for cognition. The Journal of Experimental Education, 86(1), 50-68.

https://doi.org/10.1080/00220973.2017.1380590 
Heneghan, M., Cronin, M., \& McCabe, A.

24 Consortia Academia Publishing (A partner of Network of Professional Researchers and Educators) 